\title{
First magmatism in the New England Batholith, Australia: forearc and arc-back-arc components in the Bakers Creek Suite gabbros
}

\author{
Seann J. McKibbin ${ }^{1,2, a}$, Bill Landenberger ${ }^{1}$, and C. Mark Fanning ${ }^{2}$ \\ ${ }^{1}$ School of Environmental and Life Sciences, University of Newcastle, University Drive, Callaghan, 2308, Australia \\ ${ }^{2}$ Research School of Earth Sciences, Australian National University, Bldg. 61, Mills Road, Canberra, 0200, Australia \\ ${ }^{a}$ now at: Analytical, Environmental and Geo-Chemistry, Vrije Universiteit Brussel, Pleinlaan 2, Brussels 1050, Belgium \\ Correspondence to: Seann J. McKibbin (seann.mckibbin@gmail.com, seann.mckibbin@vub.ac.be)
}

Received: 20 August 2016 - Discussion started: 31 August 2016

Revised: 28 February 2017 - Accepted: 8 March 2017 - Published: 5 April 2017

\begin{abstract}
The New England Orogen, eastern Australia, was established as an outboard extension of the Lachlan Orogen through the migration of magmatism into forearc basin and accretionary prism sediments. Widespread S-type granitic rocks of the Hillgrove and Bundarra supersuites represent the first pulse of magmatism, followed by I- and A-types typical of circum-Pacific extensional accretionary orogens. Associated with the former are a number of small tholeiitegabbroic to intermediate bodies of the Bakers Creek Suite, which sample the heat source for production of granitic magmas and are potential tectonic markers indicating why magmatism moved into the forearc and accretionary complexes rather than rifting the old Lachlan Orogen arc. The Bakers Creek Suite gabbros capture an early $(\sim 305 \mathrm{Ma})$ forearc basalt-like component with low $\mathrm{Th} / \mathrm{Nb}$ and with high $\mathrm{Y} / \mathrm{Zr}$ and $\mathrm{Ba} / \mathrm{La}$, recording melting in the mantle wedge with little involvement of a slab flux and indicating forearc rifting. Subsequently, arc-back-arc like gabbroic magmas (305-304 Ma) were emplaced, followed by compositionally diverse magmatism leading up to the main S-type granitic intrusion $(\sim 290 \mathrm{Ma})$. This trend in magmatic evolution implicates forearc and other mantle wedge melts in the heating and melting of fertile accretion complex sediments and relatively long $(\sim 10 \mathrm{Myr})$ timescales for such melting.
\end{abstract}

\section{Introduction}

The New England Orogen (NEO) is the youngest and easternmost component in the Tasmanides accretionary orogenic system and of the Australian continental craton (e.g. Cawood et al., 2011; Fig. 1a). The NEO has similarities to its older neighbour the Lachlan Orogen, such as west-dipping subduction (e.g. Leitch, 1974, 1975), a general tectonic regime switching between crustal thinning and thickening (Collins, 2002; Brown, 2003), and granitic magmatism spanning a compositional range between peraluminous and metaluminous end members (S-type and I-type for sedimentary and igneous sources respectively: Hensel et al., 1985; Chappell and White, 2001; Collins and Richards, 2008). However, the NEO represents eastward migration of magmatic activity into the Devonian-Carboniferous forearc basin and accretionary prism sediments on the margins of the Lachlan Orogen (Jenkins et al., 2002). These sediments, derived from "calc-alkaline" arc rocks, inherited juvenile isotopic characters that were passed on to their derivative granitic melts by rapid subduction cycling (Kemp et al., 2009).

In the Southern NEO, termination of the Carboniferous magmatic arc and replacement by widespread and relatively disorganised magmatism (Collins et al., 1993; Caprarelli and Leitch, 1998; Jenkins et al., 2002) culminated in the first phase of construction of the New England Batholith (Shaw and Flood, 1981), with emplacement of the contrasting Bundarra and Hillgrove S-type granitoid supersuites at $\sim 290 \mathrm{Ma}$ (Rosenbaum et al., 2012). They differ from each other with the former being a voluminous, compositionally homogenous belt, while the latter is variably foliated and generally more mafic in composition (Shaw and Flood, 1981), and it is associated with high-temperature low-pressure (HTLP) metamorphic complexes (Farrell, 1988; Dirks et al., 1992) as well as small, mafic to intermediate intrusive bodies referred to as the Bakers Creek Suite (Jenkins et al., 2002). Following 


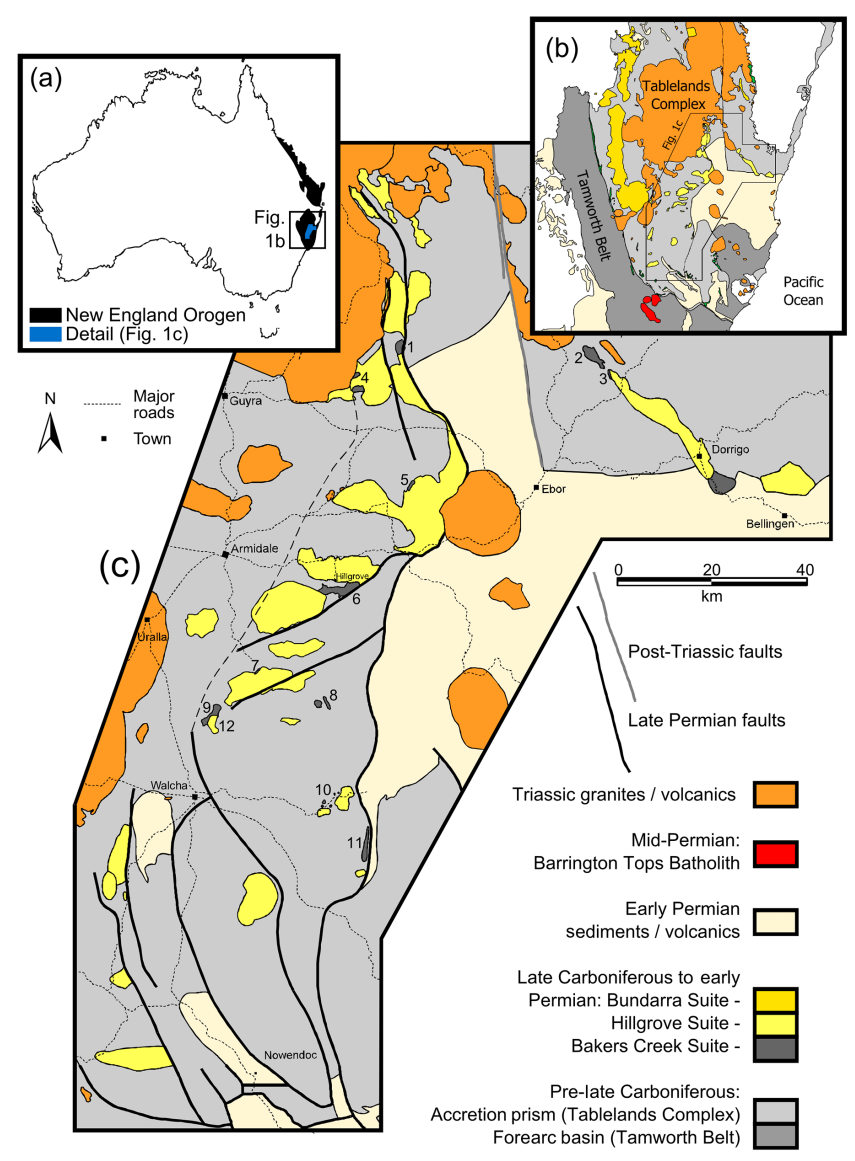

Figure 1. (a) New England Orogen (b) and field area (orange; c) on the Australian continent. (b) Southern New England Orogen outlining Tamworth Belt, Tablelands Complex, and study area (Fig. 1c). (c) Hillgrove and Bakers Creek Suite plutons in the Tablelands Complex; overlying Tertiary basalt omitted for clarity. Sampled Bakers Creek plutons: (1) Mornington; (2) Big Bull; (3) Charon Creek; (4) Days Creek; (5) Camperdown; (6) Bakers Creek; (7) Barney House; (8) Cheyenne; (9) Woodburn; (10) Moona Plains; (11) Apsley River; (12) East Lake (Hillgrove Suite).

minor magmatic activity of other types (e.g. I-type intrusions dated by Roberts et al., 1995; Donchak et al., 2007; Cross et al., 2009; Phillips et al., 2011) and a temporal magmatic gap associated with orogeny (Rosenbaum et al., 2012), the New England Batholith was overwhelmed by voluminous I-type magmatism from $\sim 265 \mathrm{Ma}$ (Li et al., 2012).

The mafic mantle-derived plutons of the Bakers Creek Suite, while small and variably evolved, ultimately record the conditions of mantle partial melting and subduction zone contributions to the first magmatism in the New England Batholith. New advances in the understanding of the geochemistry of arc-related magmas have established roles for the various mafic magmas emplaced during subduction zone initiation and migration. These include basalts with forearc (FAB; Reagan et al., 2010; Meffre et al., 2012; Ribeiro et al., 2013), back-arc (BAB; Langmuir et al., 2006; Pearce and Stern, 2006), and early arc tholeiite (EAT; Todd et al., 2012) affinities. Each of these has distinctive trace element compositions that can potentially be recognised in palaeo-arc systems (Dilek and Furnes, 2014; Pearce, 2014). We present here a study of the geochemistry of the Bakers Creek Suite with emphasis on samples from uncontaminated, mafic plutons, and $\mathrm{U}-\mathrm{Pb}$ chronology of these earliest magmatic rocks in the New England Batholith. Furthermore, we identify forearc and back-arc components and address the tectonic setting and mechanisms by which magmatism began in this section of an ancient extensional accretionary orogen.

\section{Regional geology}

The Southern NEO is built upon a metasedimentary base comprising the Tablelands Complex (an old accretionary prism) and the Tamworth Belt (a forearc basin), separated by the Peel-Manning Fault System (Leitch, 1974; Korsch, 1977; Glen and Roberts, 2012; Li et al., 2015). Both are related to a poorly exposed Devonian-Late Carboniferous magmatic arc on the margins of the Lachlan Orogen (Leitch, 1975). In the Tablelands Complex (Fig. 1b), high temperature and low pressure metamorphism overprints the accretion-subduction sequences (Wongwibinda and Tia Complexes; Farrell, 1988; Hand, 1988; Dirks et al., 1992; Phillips et al., 2008; Craven et al., 2012). Subsequently, intrusion of the Hillgrove Suite biotite granites and granodiorites ( \pm garnet, hornblende) took place, forming a discontinuous belt of scattered plutons (Flood and Shaw, 1977; Shaw and Flood, 1981). Spatially associated with the Hillgrove granitoids are the small plutons of the Bakers Creek Suite, a diverse group of mafic to intermediate bodies ranging from two-pyroxene ( \pm olivine) gabbros and related cumulate rocks through hornblende-biotite diorites to mafic hornblende-bearing granodiorites (Jenkins et al., 2002). The Hillgrove and Bakers Creek mafic plutons have been exhumed from depth as a result of early Permian rifting and subsequent thrusting during the Hunter-Bowen Orogeny (Fig. 1b; Landenberger et al., 1995; Li et al., 2014; Shaanan et al., 2015). Also present are the voluminous and more strongly peraluminous S-type granites of the Bundarra Suite, lying in a continuous north-trending belt to the west of the Hillgrove Suite (Flood and Shaw, 1977; Shaw and Flood, 1981). In contrast to the Hillgrove Suite, the Bundarra Suite granites are generally non-foliated, have no mafic plutons associated with them, and are not associated with metamorphic complexes, despite generally contemporaneous intrusion (Rosenbaum et al., 2012).

Mafic, primitive members of the Bakers Creek Suite include the small Barney House and Big Bull gabbros, while larger plutons such as the Days Creek gabbro and Apsley River Complex exhibit more complex characteristics of differentiation (e.g. samples BHC2, CC26A, G39, and GK2 respectively from Jenkins et al., 2002). Sampling was undertaken with a focus on mafic plutons such as the Bar- 

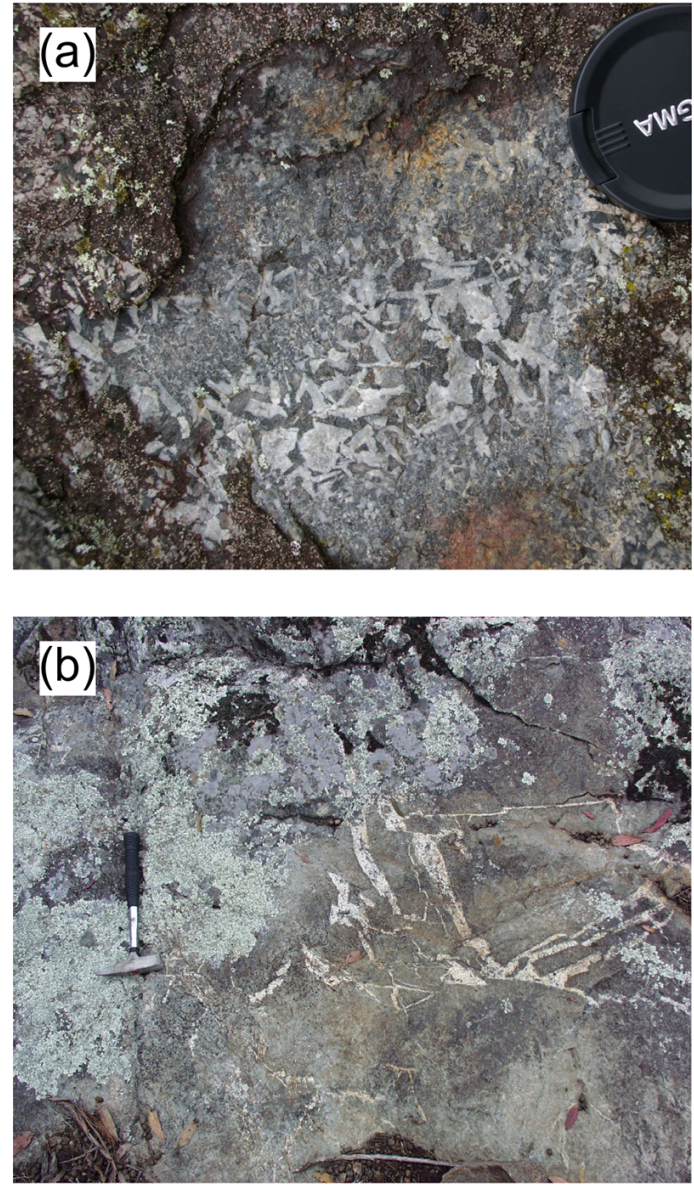

Figure 2. Photos of the Days Creek Gabbro showing (a) massive gabbro enclosing domain of gabbro pegmatite. Camera lens has a diameter of $5 \mathrm{~cm}$; (b) finer-grained dolerite pluton margin hosting felsic veins. Hammer length $30 \mathrm{~cm}$.

ney House, Big Bull, and Days Creek gabbros. The Barney House and Big Bull gabbros are small (scale of tens to hundreds of metres) and consist of finely crystalline gabbro, often hosting plagioclase phenocrysts, in contact with lowgrade metasedimentary country rock. The Big Bull Gabbro occurs as the most mafic member in a full spectrum of rocks, varying from mafic to felsic (Sheep Station Creek Complex). In contrast, the Days Creek Gabbro occurs as two larger plutons ( $\sim 1$ and $\sim 2 \mathrm{~km}$ in length), partially surrounded by the Tobermory Monzogranite (Hillgrove Suite), except at the southern margin where it borders turbidites of the Girrakool beds. It is dominated by medium to coarse grained gabbro and contains rare pegmatite (grain size 5-20 mm; Fig. 2a). The southern pluton exhibits a doleritic $(\sim 1 \mathrm{~mm})$ chilled margin against turbidites, which are contact-metamorphosed and exhibit rare occurrences of melting. Widespread but poorly exposed pieces of dolerite are found at various locations across both plutons, some in association with metasedimentary rocks and felsic veins containing gabbro breccia
(Fig. 2b). The encompassing Tobermory Monzogranite is usually coarse (average grain size a few millimetres) and lacks foliation. Although most contacts are not exposed, it is often finer grained (to $\sim 1 \mathrm{~mm}$ ) nearer the gabbro, indicative of quenching and late emplacement relative to most other members of the Hillgrove Suite (Landenberger et al., 1995). The Tobermory Monzogranite is cut on the western side by younger, unrelated mid-late Permian to Triassic I-type granite (Li et al., 2012).

\section{Analytical methods}

Selected $30 \mu \mathrm{m}$ thin sections of samples were polished and carbon coated for X-ray analysis of mineral phases by scanning electron microprobe (SEM) at the University of Newcastle (UoN) using a Phillips XL30 SEM, with an Oxford ISIS energy dispersive spectrometer (EDS), $15 \mathrm{kV}$ accelerating voltage, and $3 \mathrm{nA}$ beam current. Bulk-rock samples were crushed by a tungsten carbide mill and losses on ignition were determined by weighing before and after heating in air at $\sim 1000^{\circ} \mathrm{C}$. These powders were then diluted in lithium borate flux at $1050{ }^{\circ} \mathrm{C}$ to produce a glass disc. Major element oxides $\left(\mathrm{Na}_{2} \mathrm{O}, \mathrm{MgO}, \mathrm{Al}_{2} \mathrm{O}_{3}, \mathrm{SiO}_{2}, \mathrm{P}_{2} \mathrm{O}_{5}, \mathrm{~K} 2 \mathrm{O}, \mathrm{CaO}, \mathrm{TiO}_{2}\right.$, $\mathrm{MnO}$, and $\mathrm{FeO}$ ) and trace elements $(\mathrm{Pb}, \mathrm{P}, \mathrm{Ti}, \mathrm{V}, \mathrm{Mn}, \mathrm{Zn}$, and $\mathrm{Cr}$ reported here) were analysed by $\mathrm{X}$-ray fluorescence (XRF) spectrometry at the UoN (Spectro X-Lab 2000 XRF system with $\mathrm{EDS}, \mathrm{Pb}$ anode tube, polarised beam, multiple targets). All $\mathrm{Fe}$ is reported as $\mathrm{FeO}$. Glass XRF discs from this study and from Jenkins et al. (2002) were sectioned and polished for further trace element analysis $(\mathrm{Cs}, \mathrm{Rb}, \mathrm{Ba}, \mathrm{Th}$, $\mathrm{U}, \mathrm{Nb}, \mathrm{Ta}, \mathrm{Sr}, \mathrm{Zr}, \mathrm{Hf}, \mathrm{Ga}, \mathrm{Y}, \mathrm{Sc}, \mathrm{Co}, \mathrm{Ni}$, and the rare earth elements La, Ce, Pr, Nd, Sm, Eu, Gd, Dy, Er, and Yb) by laser ablation inductively coupled plasma mass spectrometry at the Research School of Earth Sciences, Australian National University (ANU), using a quadrupole Agilent 7500 s coupled to a $193 \mathrm{~nm}$ argon fluoride Excimer laser (Eggins, 2003). Samples were analysed in parallel with NIST 612 (primary normalisation standard) and BCR-2g (secondary external standard) glasses, and either ${ }^{43} \mathrm{Ca}$ or ${ }^{29} \mathrm{Si}$ were used as internal standards, depending on bulk silica content (using $\mathrm{CaO}$ or $\mathrm{SiO}_{2}$ from XRF). Data were reduced using an in-house spreadsheet. Further details are given in Supplement S5.

Magmatic zircon ${ }^{238} \mathrm{U} /{ }^{206} \mathrm{~Pb}$ ages of gabbroic and dioritic samples were determined at the ANU using sensitive highresolution ion microprobes (SHRIMP). The gabbroic samples (Barney House and Days Creek gabbros) were analysed using SHRIMP-RG (reverse geometry) against the reference standard TEMORA, while dioritic samples (Bakers Creek Complex and Charon Creek Diorite) were analysed using SHRIMP-I against the AS3 reference material. Rejection of analyses was made on the basis of measurable common $\mathrm{Pb}$, loss of $\mathrm{Pb}$, or contribution to an unreasonably high mean square of weighted deviates (MSWD). In reviewing other U$\mathrm{Pb}$ data for the NEO in the literature, it is noted that they were 
obtained against a range of reference materials over many years. The comparative study of Black et al. (2003) showed that some zircon ion-probe reference materials yielded small biases, with ages calculated against AS3 being $\sim 1 \%$ too high and ages calculated against SL13 being variably (although on average $\sim 1 \%$ ) too low. To account for this, we made corrections of $-1 \%$ to our AS3 ages and $+1 \%$ to SL13 ages assembled in our age compilation; other relevant AS3 ages in the literature were verified by other standards (Roberts et al., 2004, 2006). Although these corrections are significant in terms of precision, they have little influence on tectonic conclusions.

More importantly, some of the U-Pb ages for early NEO magmatism, the S-type Rockvale Granodiorite and Tia Granodiorite, as well as the I-type Halls Peak Volcanics, appear biased towards younger ages by rejection criteria. Cawood et al. (2011) presented ages for these and other igneous bodies, undertaken against reliable standards (CS3) that do not require corrections of the kind discussed above. However, they included an arbitrary criterion for recognition of zircon inheritance, namely that analyses older than 300 Ma should be excluded. Because individual zircon $\mathrm{U}-\mathrm{Pb}$ determinations for these samples have approximately Gaussian distributions centred near $300 \mathrm{Ma}$, this has led to an excessive number of rejections and naturally to ages $<300 \mathrm{Ma}$ (Rockvale Granodiorite: $292.6 \pm 2.4 \mathrm{Ma}$, MSWD 1.5, 10 from 30 rejected; Tia Granodiorite: $295.7 \pm 2.8 \mathrm{Ma}$, MSWD 0.37, 14 from 27 rejected; and Halls Peak Volcanics: 292.6 $\pm 2.0 \mathrm{Ma}$, MSWD $0.68 ; 11$ from 26 rejected). An alternative criterion for recognition of zircon inheritance follows from the observation of Jeon et al. (2012) that the Th / U ratios of obviously inherited zircon in the Bundarra Supersuite are generally greater than $\sim 0.3$, while new magmatic zircon extends to as low as $\sim 0.05$. We have recalculated the ages of these samples with an emphasis on including zircon with low $\mathrm{Th} / \mathrm{U}$ and maintaining Gaussian distributions.

\section{Petrography}

Fine-grained, doleritic Barney House, Big Bull (Sheep Station Creek Complex) and Days Creek gabbros exhibit granular and flow-foliated (Fig. 3a) to ophitic-subophitic textures (Fig. 3b) and occasionally contain phenocrystic or glomerocrystic plagioclase (Fig. 3c). Plagioclase is elongate, subrectangular, or lath-like, sharing irregular edges with or enclosing olivines, and it is typically normally zoned or unzoned, but sometimes contains distinct cores $\left(\mathrm{An}_{72-60}\right.$ in groundmass; mostly $\sim \mathrm{An}_{80}$ but up to $\mathrm{An}_{86}$ in cores). Phenocryst rims are sodic (to $\mathrm{An}_{50}$ ) and texturally interlock with the fine gabbro groundmass. Olivine $\left(\mathrm{Fo}_{62}-72\right)$ is common and exhibits rounded, irregular, and embayed morphologies or is very rarely interstitial and mantled by pyroxene or hornblende. Pyroxene occurs as oikocrysts and interstitial crystals. High-Ca clinopyroxene (diopside-augite Mg\# 78)
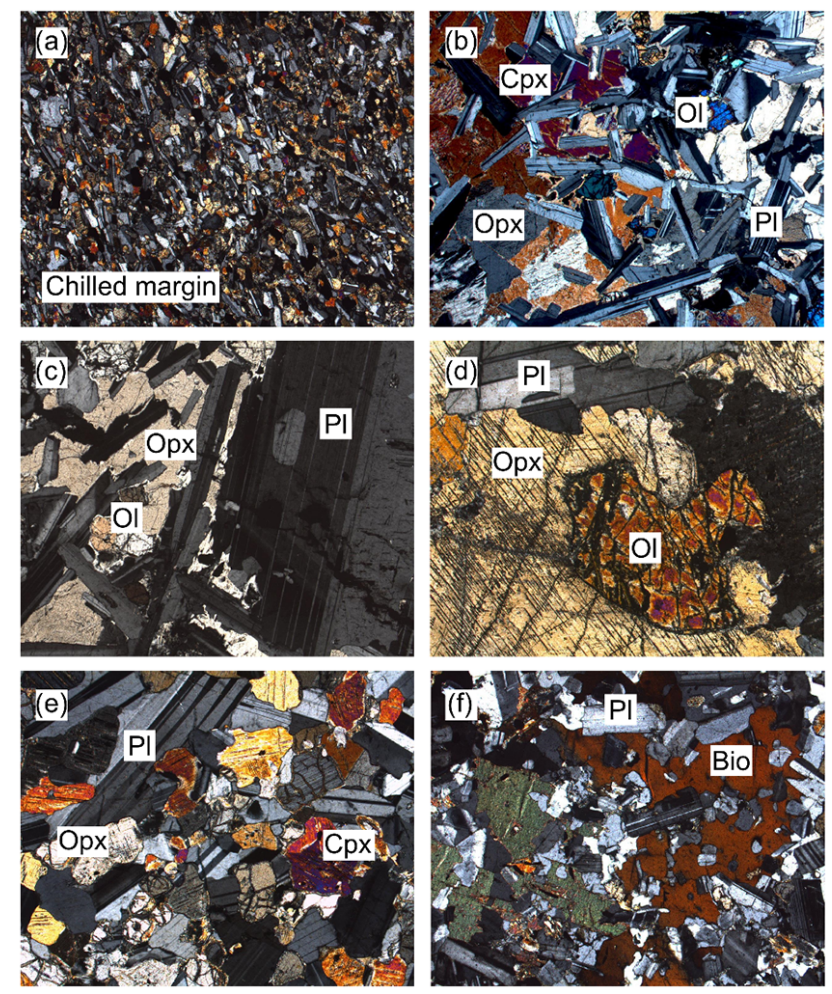

Figure 3. Cross-polarised light images of gabbroic rocks; all image field of views are $2 \mathrm{~mm}$. (a) Chilled, flow-foliated margin of the Days Creek Gabbro DC65. (b) Ophitic micro-gabbro in Barney House Gabbro BH30. (c) Phenocrystic plagioclase in Barney House gabbro BH45. (d) Relict olivine in massive Days Creek Gabbro DC19. (e) Granular Days Creek Gabbro DC36. (f) Poikilitic biotite-diorite associated with Days Creek Gabbro DC98.

is more common than low-Ca orthopyroxene (Mg\# 71) and contains exsolution lamellae of the latter. Pyroxene shares interstices with calcic magnesio-hastingsite hornblende and

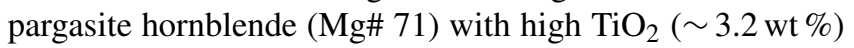
and $\mathrm{Al}_{2} \mathrm{O}_{3}(\sim 11.0 \mathrm{wt} \%)$, as well as small titanium-rich phlogopite $\left(\sim 3.9 \mathrm{wt} \% \mathrm{TiO}_{2}\right.$; average $\left.\mathrm{Mg \#} 75\right)$. Ilmenite and rare magnetite (sometimes intergrown) is usually associated with amphibole and phlogopite, often being mantled by them or included in their interstitial domains.

Coarsely crystalline gabbro (millimetre to centimetre crystals) is more typical of the Days Creek Gabbro, with orthocumulate or mesocumulate textures (Fig. 3d) comprising plagioclase, rare resorbed olivine, high-Ca clinopyroxene, very rare low-Ca orthopyroxene, ilmenite, and amphibole (latter often secondary). Massive coarse-grained gabbro also has rare granular texture (Fig. 3e). Plagioclase $\left(\mathrm{An}_{80-47}\right)$ ranges from isolated, equant euhedral crystals to subhedral crystals in an interlocking network, defining the ortho- or mesocumulate texture. They are commonly normally zoned and rarely exhibit oscillatory zoning or scissor deformation twins. Olivine is Fo $65-59$ and is anhedral or 

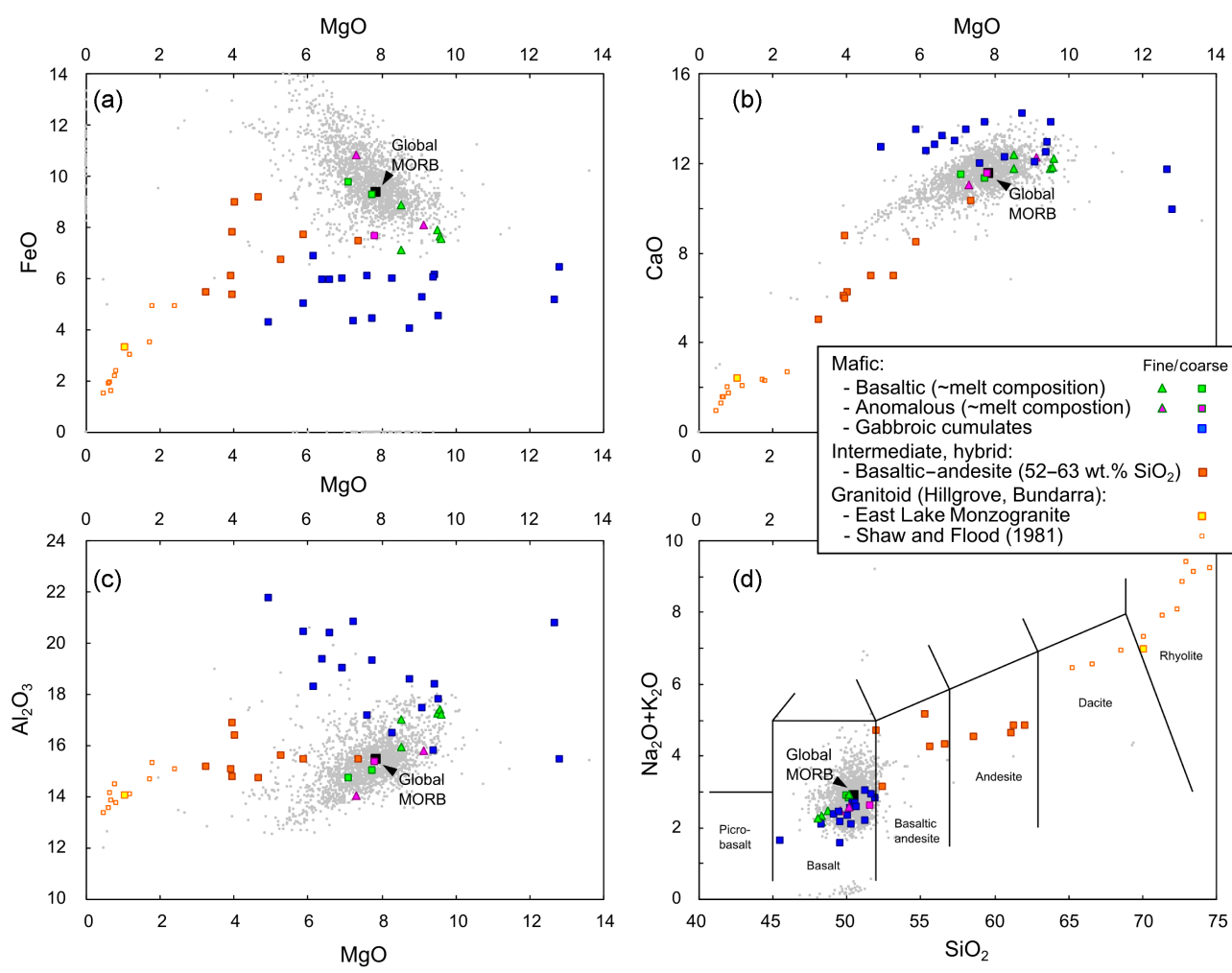

Figure 4. Major element chemistry of bulk samples. Finely crystalline, doleritic samples in triangles and coarsely crystalline samples in squares. Samples likely to represent melt compositions and anomalous samples (on the basis of unusual trace element contents; see Fig. 5) also likely to represent melt compositions are given in green and pink respectively. Cumulate gabbroic samples are in blue and mid-silica (compositionally basaltic andesite or andesite) rocks of probable hybrid origin (mantle-crust mixtures) are given in orange. Yellow squares indicate a single granitic sample of the East Lake Monzogranite (Hillgrove Suite). Other Hillgrove as well as Bundarra Suite samples from the classic study of Shaw and Flood (1981) are given as small orange squares. The global MORB identified by Arevalo and McDonough (2010) is presented as a large black square; MORB data from that study and from Jenner and O'Neill (2012) and the PetDB screening by Class and Lehnert (2012) are presented as small grey points. Fenner diagrams present $\mathrm{MgO}$ versus (a) $\mathrm{FeO}$, with the trend defined by inferred melt compositions (in green field) indicating a tholeiitic association; (b) $\mathrm{CaO}$; and (c) $\mathrm{Al}_{2} \mathrm{O}_{3}$. (d) Total alkalis vs. silica (TAS) diagram.

embayed. Secondary clinozoisite and serpentinite after plagioclase and olivine was not observed in fine-grained gabbros but is present in coarse-grained samples. Pyroxenes are subhedral or interstitial and are rarely optically continuous across multiple domains. In coarse gabbros, high-Ca clinopyroxene is diopside-augite (average $\mathrm{Mg} \#$ 79), while low-Ca orthopyroxene is very rare, possibly because of uralitisation (Mg\# 70 with exsolved clinopyroxene at Mg\# 78). Very fine orthopyroxene exsolution is also present in clinopyroxenes. Amphibole is present in abundance approximately equal to that of pyroxenes and occurs as primary interstitial magnesio-hornblendes (pale brown and green; average Mg\# 63) and secondary fibrous or radiating irregular actinolitic hornblende, magnesio-hornblende, or tschermakitic hornblende (green to green-blue varieties; average Mg\# 60). Anhedral or interstitial ilmenite shares intercumulus spaces with pyroxenes and amphiboles.

Bakers Creek Suite rocks with higher silica contents (geochemically intermediate between gabbros and granitoids of the Hillgrove Suite) display a wide range of textures and variation in mineralogy. Poikilitic, equigranular, and foliated textures are observed in rocks from parts of the Days Creek Gabbro, Camperdown Complex, and Woodburn Diorite. In poikilitic biotite-diorite associated with the Days Creek Gabbro, small rectangular or subhedral plagioclase and granular orthopyroxene are randomly enclosed within large oikocrysts of biotite, quartz, and orthopyroxene (sample DC98; Fig. 3f). Equigranular diorite from the Camperdown Complex (CC11) is dominated by subhedral plagioclase with green amphibole in large interstitial quartz domains, with possibly secondary green amphibole and calcite. More felsic varieties of the Bakers Creek Suite are closer in composition to and continuous with that of the Hillgrove Suite granitoids and have developed tectonic foliations or sub-gneissic textures, e.g. the Woodburn Diorite is composed of subhedral plagioclase and amphibole, folded or kinked biotites, and interstitial or ophitic quartz domains (WB32). Quartz and plagio- 
clase are occasionally graphically intergrown. Preferentially aligned biotite is the main contributor to foliation.

\section{Geochemistry}

Samples of the Bakers Creek Suite cover a broad geochemical range (Fig. 4a and Supplement S1). Mafic samples with finely crystalline gabbroic or doleritic textures exhibit generally increasing $\mathrm{FeO}, \mathrm{Na}_{2} \mathrm{O}, \mathrm{P}_{2} \mathrm{O}_{5}$, and $\mathrm{TiO}_{2}$ as $\mathrm{MgO}, \mathrm{CaO}$, and $\mathrm{Al}_{2} \mathrm{O}_{3}$ decrease (Fig. $4 \mathrm{a}, \mathrm{b}$, and c); they define a trend that passes across mid-ocean ridge basalt (MORB) compositions for major elements (e.g. Jenner and O'Neill, 2012; Class and Lehnert, 2012; and the global MORB identified by Arevalo and McDonough, 2010). The Big Bull Gabbro (CC26A) is a close but resolvable outlier to this trend for some elements (e.g. FeO). From their petrography they likely represent liquid compositions; a range of $\mathrm{FeO} / \mathrm{MgO}$ for similar $\mathrm{SiO}_{2}$ is therefore indicative of tholeiitic style evolution (Arculus, 2003; Zimmer et al., 2010). In contrast, coarsely crystalline gabbros do not follow this trend for most oxides. With decreasing $\mathrm{MgO}$, they have increasing $\mathrm{Al}_{2} \mathrm{O}_{3}$, $\mathrm{P}_{2} \mathrm{O}_{5}$, and $\mathrm{TiO}_{2}$ but $\mathrm{FeO}, \mathrm{CaO}, \mathrm{Na}_{2} \mathrm{O}, \mathrm{SiO}_{2}$, and $\mathrm{K}_{2} \mathrm{O}$ are poorly related to $\mathrm{MgO}$ (e.g. Fig. 4a, b, and c). All gabbroic samples, whether coarse or finely crystalline, have low $\mathrm{K}_{2} \mathrm{O}$ $(<0.3 \mathrm{wt} \%$; low-K association of Gill, 1981) and are basaltic (Le Bas and Streckeisen, 1991). With our focus on the mafic end member, most of our samples are basaltic (i.e. doleritic) or gabbroic (45.5-52 wt \% $\mathrm{SiO}_{2}$ ), but some dioritic samples were also collected (basaltic-andesitic or andesitic compositions of up to $61.3 \mathrm{wt} \% \mathrm{SiO}_{2}$ ) and we also report one granitic sample from the East Lake Monzogranite, associated with the Woodburn Diorite $\left(\sim 70 \% \mathrm{SiO}_{2}\right)$. Dioritic samples span the range between Bakers Creek gabbroic and Hillgrove Suite granitic compositions through "basaltic andesite" to "dacite-rhyolite" (e.g. $\sim 52-62 \mathrm{wt} \% \mathrm{SiO}_{2}$ and $0.5-2.0 \mathrm{wt} \%$ $\mathrm{K}_{2} \mathrm{O}$; Fig. 4d). Some samples deviate from this trend to higher or lower levels of minor element contents (e.g. samples MP2, CCD, and GK5, FHB respectively). The granitic sample (EA31) falls within or near the main group of Hillgrove Suite samples for all major elements (e.g. Shaw and Flood, 1981).

There is a general correlation between major element and trace element geochemistry, with gabbroic samples having MORB-like trace and rare earth element (REE) abundances, while samples with intermediate and/or granitic geochemistry are enriched in incompatible trace and REEs (Fig. 5; multi-element plots normalised to global MORB of Arevalo and McDonough, 2010). In detail, most of the finely crystalline gabbros display flat and very MORB-like trace element patterns, especially for high-field-strength elements (HFSEs) Zr, Hf, Ti, Y as well as REE, but with positive Cs, $\mathrm{Rb}, \mathrm{Ba}, \mathrm{Th}, \mathrm{U}$, and $\mathrm{Pb}$ anomalies and depletions in $\mathrm{Nb}$ and $\mathrm{Ta}$ (e.g. Barney House and Big Bull gabbros). In combination with finely crystalline micro-gabbroic or doleritic tex- tures, we interpret these samples to reflect melt compositions, rather than cumulate excesses of one or more minerals. Some coarsely crystalline gabbros (DC15, DC16) are geochemically similar to the fine-grained gabbros and may also reflect melt compositions via mostly in situ crystallisation. However, most gabbros are variably depleted in HFSE, REE, Th, $\mathrm{Nb}, \mathrm{Ta}$, and $\mathrm{P}$, with positive anomalies for the same elements as in the finely crystalline gabbros $(\mathrm{Cs}, \mathrm{Rb}, \mathrm{Ba}, \mathrm{Th}, \mathrm{U}$, and $\mathrm{Pb}$ ) but also including $\mathrm{Eu}$. $\mathrm{Cr}$ and $\mathrm{Ni}$ are variable, with some exhibiting clear enrichments (e.g. GK5 and FHB). Coarsely crystalline samples from the Days Creek Gabbro with middle and high-range $\mathrm{Mg \#}$ display erratic, concave up patterns, with elevated lare ion lithophile elements (LILE) and $\mathrm{Sr}$; low $\mathrm{Nb}$, Ta, and HFSEs; and higher abundances of $\mathrm{Cr}$ and $\mathrm{Ni}$. REE patterns are flat with considerable variation in absolute abundances, and as for finely crystalline samples, they are generally correlated with $\mathrm{FeO}$. For samples with higher Mg\#, REE abundances are lower and distinct $\mathrm{Eu}$ anomalies and light REE depletions are apparent. Some gabbros from the Days Creek Gabbro appear to be anomalous (D12, DC104, and DC65) with variable depletion in $\mathrm{Cs}$, Th, $\mathrm{U}, \mathrm{Nb}, \mathrm{Ta}, \mathrm{K}$, $\mathrm{P}, \mathrm{Zr}, \mathrm{Hf}$, and light REE and potential enrichment in Ba.

Trace and REE concentrations for higher silica, geochemically intermediate rocks of the Bakers Creek Suite, as well as the East Lake Monzogranite sample (Hillgrove Suite; EA31), are variably higher and patterns are inclined; peaks in Cs, $\mathrm{Th}, \mathrm{U}, \mathrm{K}, \mathrm{Pb}, \mathrm{Zr}$, and $\mathrm{Hf}$ alternate with negative $\mathrm{Nb}, \mathrm{Ta}, \mathrm{Sr}$, $\mathrm{P}$, and Ti anomalies. The Hillgrove Suite sample is the most enriched in incompatible trace elements, and other geochemically intermediate samples also exhibit generally intermediate concentrations of such elements, i.e. they are correlated with $\mathrm{SiO}_{2}$. Negative anomalies are common for $\mathrm{Ba}, \mathrm{Nb}$, and $\mathrm{Ta}$, with some variation in HFSE where concentrations are similar to the granites. $\mathrm{Cr}$ and $\mathrm{Ni}$ likewise display a range intermediate to the gabbros and granites. Though higher silica samples of the Bakers Creek Suite have compositions intermediate to the gabbros and the monzogranite for most elements, there are important exceptions for $\mathrm{Sr}, \mathrm{P}, \mathrm{Ti}, \mathrm{Eu}$, and heavier REEs for certain samples (CCD, MP2, DC98). These characteristics are consistent with a hybrid origin via mixing of basaltic and granitic components.

\section{Zircon chronology}

We find zircon ${ }^{206} \mathrm{~Pb} /{ }^{238} \mathrm{U}$ ages of $303.9 \pm 3.2 \mathrm{Ma}$ (15 points with no rejections, MSWD 1.7) for the Barney House Gabbro and $305.1 \pm 2.9 \mathrm{Ma}$ (18 points with 1 rejection, MSWD 1.5) for the Days Creek Gabbro. These are the oldest ages for intrusive rocks in the Southern NEO, with the possible exceptions of the Rockvale and Tia granodiorites (see below). The Bakers Creek Complex has a similar age of $299.3 \pm 3.1 \mathrm{Ma}$ (corrected for AS3; uncorrected age is $302.3 \pm 3.1 \mathrm{Ma}, 18$ points with 2 rejections, MSWD 1.3), while the Charon Creek Diorite has a younger age of $290.4 \pm 3.2 \mathrm{Ma}$ (corrected 


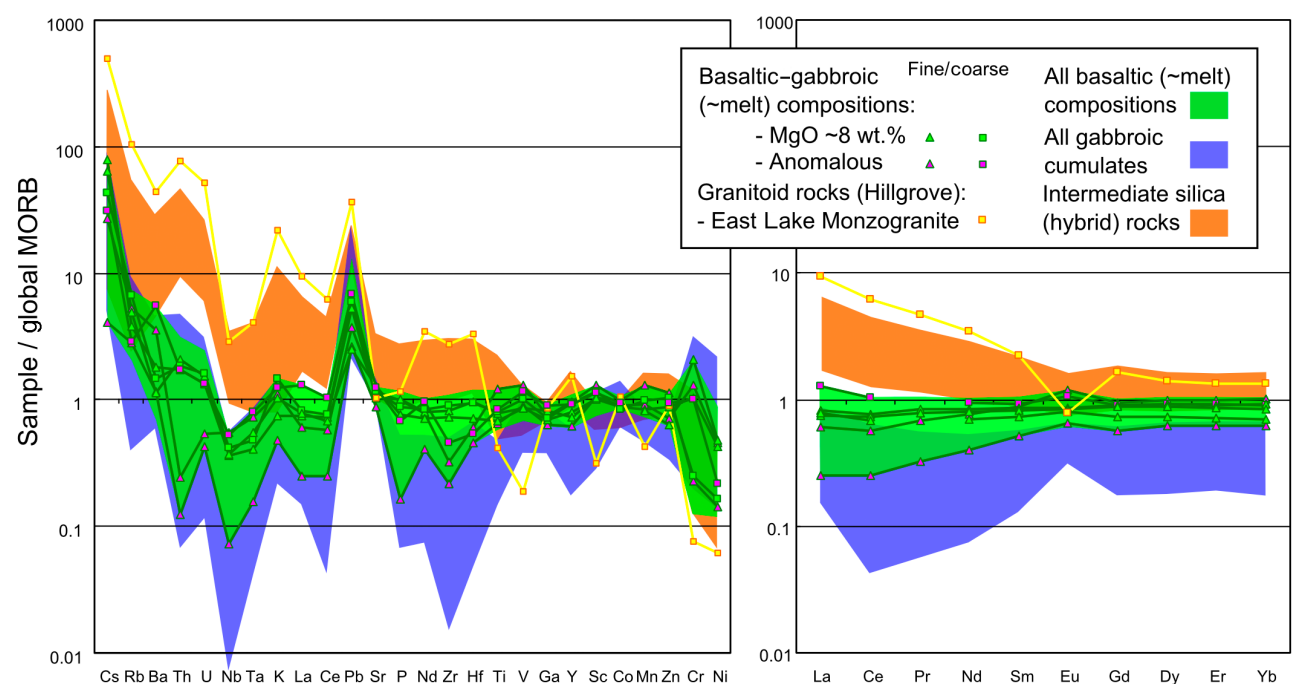

Figure 5. Trace element chemistry of bulk samples, normalised to global MORB (Arevalo and McDonough, 2010). Finely and coarsely crystalline gabbros (triangles and squares respectively) that approximate melt compositions with $\sim 8 \mathrm{wt} \% \mathrm{MgO}$ are in green; anomalous melt compositions in pink; East Lake Monzogranite (Hillgrove Suite) in yellow. Range of compositions for basaltic melts, cumulates, and higher silica (basaltic andesite or andesitic) hybrid melts are given by green, blue, and orange fields respectively.
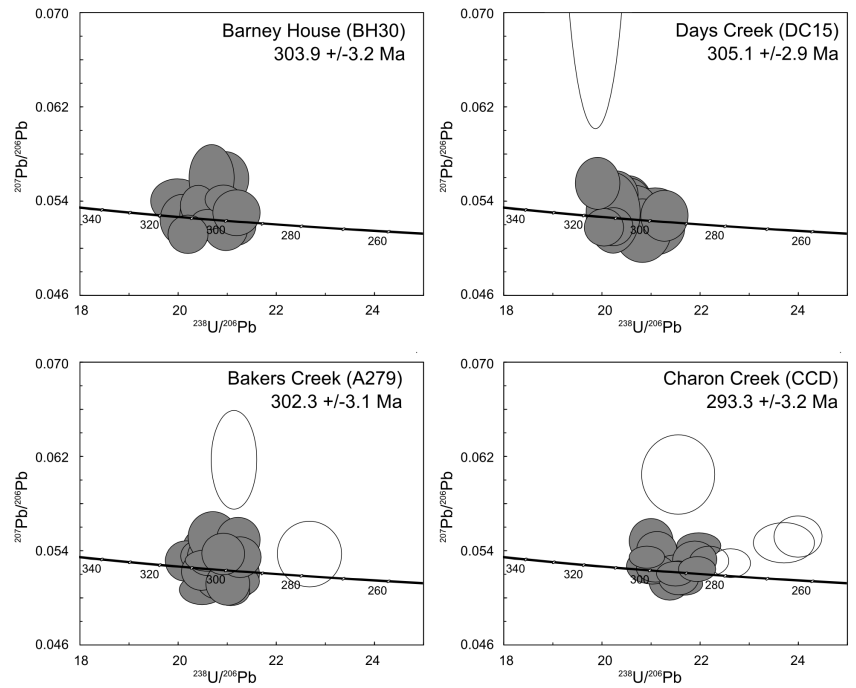

Figure 6. Tera-Wasserburg concordia plots of $\mathrm{U}-\mathrm{Pb}$ data for Bakers Creek samples. Individual spot error ellipses are $68.3 \%$ confidence limits. Unfilled ellipses were not included in weighted mean age calculations; age intervals are $95 \%$ confidence and include error on standards.

for AS3; uncorrected age is $293.3 \pm 3.2 \mathrm{Ma}, 15$ points and 5 rejections on the basis of $\mathrm{Pb}$ loss or measurable common $\mathrm{Pb}$, MSWD 1.6). U-Pb data are given in Fig. 6 and Supplement S2.

With our Th / U criteria, the recalculated age of the Rockvale Granodiorite is $296.7 \pm 2.3 \mathrm{Ma}$ (MSWD 1.8), $\sim 4 \mathrm{Myr}$ older than the age given by Cawood et al. (2011; Supplement $\mathrm{S} 3$ ). We revisited the original $\mathrm{U}-\mathrm{Pb}$ age for the
Rockvale Granodiorite reported by Kent (1994), which at $303 \pm 3 \mathrm{Ma}$, is older than other igneous rocks of the Southern NEO. His rejection criteria were fundamentally in accord with ours, although the age may suffer from variable bias from the SL13 standard, which would have depressed the age. If bias were, in this case, insignificant (SL13 behaviour is not consistent and sometimes does not bias ages at all; Black et al., 2003), then a discrepancy of 1.0 Myr would remain between Kent (1994) and the age recalculated from the data of Cawood et al. (2011). If, however, bias is present, then the age could be up to $\sim 306 \mathrm{Ma}$, with associated discrepancy of up to $\sim 4 \mathrm{Myr}$. Hence, U-Pb data for the Rockvale Granodiorite remain poorly understood.

Our recalculated age of the Tia Granodiorite is $299.7 \pm 2.0 \mathrm{Ma}$ (MSWD 0.92), again $\sim 4 \mathrm{Myr}$ older than reported by Cawood et al. (2011). This age is consistent with previous U-Pb determinations $(\sim 300$ and $\sim 302 \mathrm{Ma}$ from Dirks et al., 1993 and Kemp et al., 2009), which together with ages for the Rockvale Granodiorite, imply that the intrusion of some Hillgrove Supersuite plutons considerably predated the main S-type flux represented by the Bundarra Supersuite and most of the Hillgrove Supersuite. For the Halls Peak Volcanics, the recalculated age is $295.7 \pm 2.2 \mathrm{Ma}$ (MSWD 1.6), $\sim 3 \mathrm{Myr}$ older than given by Cawood et al. (2011). Selected and rejected zircon analyses from Cawood et al. (2011) are given in Supplement S3. 

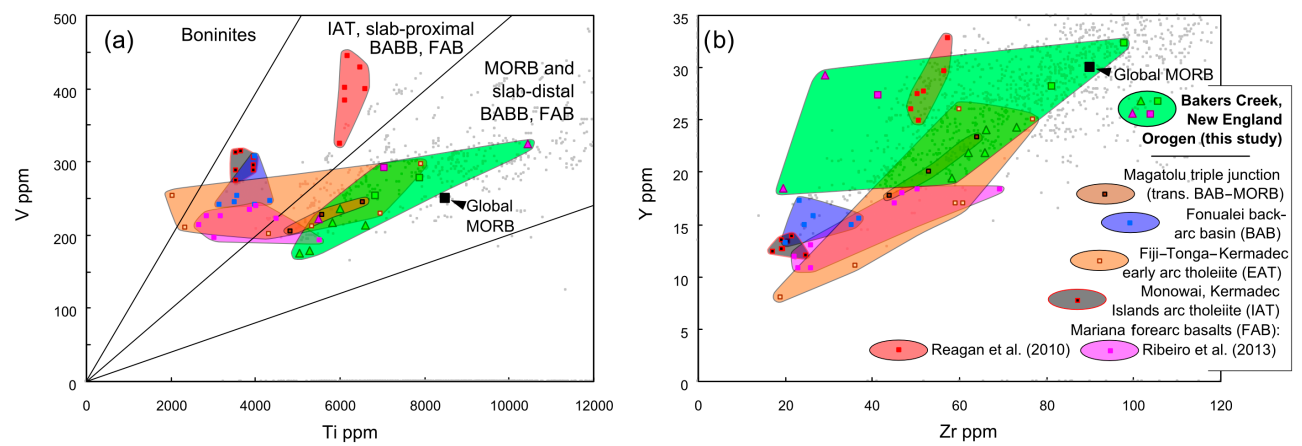

Figure 7. Ti-V and Zr-Y systematics of Bakers Creek Suite melt compositions and selected primitive melts from western Pacific arc systems (Keller et al., 2008; Reagan et al., 2010; Timm et al., 2011; Escrig et al., 2012; Ribeiro et al., 2013; Todd et al., 2012; Kemner et al., 2015). Ti-V fields from Shervais (1982) and Pearce (2014).

\section{Discussion}

\subsection{Tectonic setting: BAB, EAT, FAB, or something else?}

The wide range of compositions present in chilled margins, including anomalous (e.g. DC65) and main-group samples (e.g. $\mathrm{BH} 30$ ) of various $\mathrm{MgO}$ contents, indicates trapping of melt compositions after magmatic differentiation that occurred before or during emplacement of magmas during ascent through the mantle wedge and overlying crust. Some differentiation also seems to have occurred in situ, indicated by coarsely crystalline samples DC15 and DC16, which are geochemically similar to quenched or finely crystalline gabbros. We identify likely melt compositions by green and purple in Figs. 4, 5, 7, and 8.

Our melt compositions lie in the MORB and slab-distal BAB and FAB fields in terms of Ti and V (Shervais, 1982; Pearce, 2014; Fig. 7a), and they seem to have only been subtly affected by subduction zone influences on these elements (McCulloch and Gamble, 1991; Woodhead et al., 2001). Alternately, $\mathrm{Y} / \mathrm{Zr}$ can be used to identify previously depleted mantle sources (e.g. Arculus et al., 2015). Despite the geochemical similarity of these elements to V / Ti under typical subduction zone redox conditions (trivalent and tetravalent respectively), there is clear distinction between main-group Bakers Creek Suite melt compositions and anomalous melts in Y / Zr space (Fig. 7b; samples DC65, DC104, and D12). These have much lower $\mathrm{Zr}$ (and Hf) for similar Y contents, which is a characteristic shared by FABs, e.g. Izu-Bonin FAB (Reagan et al., 2010; Ribeiro et al., 2013; Arculus et al., 2015).

Despite MORB-like Ti-V and Zr-Y systematics for most Bakers Creek Suite melt compositions, a subduction-derived component is clear for slab flux elements. In $\mathrm{Nb} / \mathrm{Yb}$ and $\mathrm{Th} / \mathrm{Yb}$ space (Pearce, 2014) the main group of samples are well clear of the MORB and ocean island basalt array and are high in the "oceanic arcs" region (Fig. 8a), while two anomalous samples again share similarities with FAB-type basalts in having very low Th / Yb, consistent with Zr-Y (but not Ti-V) systematics. Multi-element plots in Fig. 5 suggest that this is due to a combination of (1) $\mathrm{Nb}$ depletion, either by retention in the mantle-wedge source or an undercontribution from the slab, and (2) addition of Th (and U) to main-group Bakers Creek Suite melts via addition of a sedimentary component (e.g. Woodhead et al., 2001). The latter might have been derived from subducted sediments in the undergoing slab or by simple contamination with Lachlan Orogen accretionary prism material as metasediments or S-type granitic melts (i.e. Hillgrove Suite). Anomalous Bakers Creek Suite melts DC65 and DC104 are in the extension of the MORB array to very low $\mathrm{Th} / \mathrm{Yb}$ and low or very low $\mathrm{Nb} / \mathrm{Yb}$. Along with $\mathrm{Th}$, the similarly incompatible indicators of sedimentary melting $\mathrm{U}$ and light REE (especially $\mathrm{La}$ and $\mathrm{Ce}$ ) seem to have been under-contributed (no melting of zoisite or allanite; Spandler and Pirard, 2013), although the Th / U ratio of DC65 and DC104 is much lower than other samples. DC65 and D12 received unusually high Ba contributions, which may indicate a distinct fluid component (Woodhead et al., 2001). Anomalous samples are therefore associated with a peculiar elevated Ba / La (Fig. 8b). Additionally, DC104 has much lower Cs values (and $\mathrm{K}_{2} \mathrm{O}$ ) than the others, despite similar levels of $\mathrm{Rb}$ in main-group and anomalous Bakers Creek Suite samples. This strongly indicates decoupling of $\mathrm{Rb}$ from other trace alkalis Cs and $\mathrm{K}_{2} \mathrm{O}$, as well as from $\mathrm{Ba}$, elements that are ordinarily associated in sub-arc settings, e.g. via phengite and paragonite melting (Spandler and Pirard, 2013).

A direct comparison is made of the multi-element plots for the melt compositions of the Bakers Creek Suite, with the FAB basalts of Reagan et al. (2010) and Ribeiro et al. (2013) in Fig. 9, for similar major element compositions (especially for $\mathrm{MgO}$, in the range $\sim 6.6-8.6 \mathrm{wt} \%$ ). They share some relative and absolute abundance trace element characteristics, especially those of anomalous composition (D12, DC104, and DC65). Low abundances of certain slab-flux elements, such as Th and U; the light to mid-REEs, especially La and $\mathrm{Ce}$ (and consequently low light REE to heavy REE ratio); 

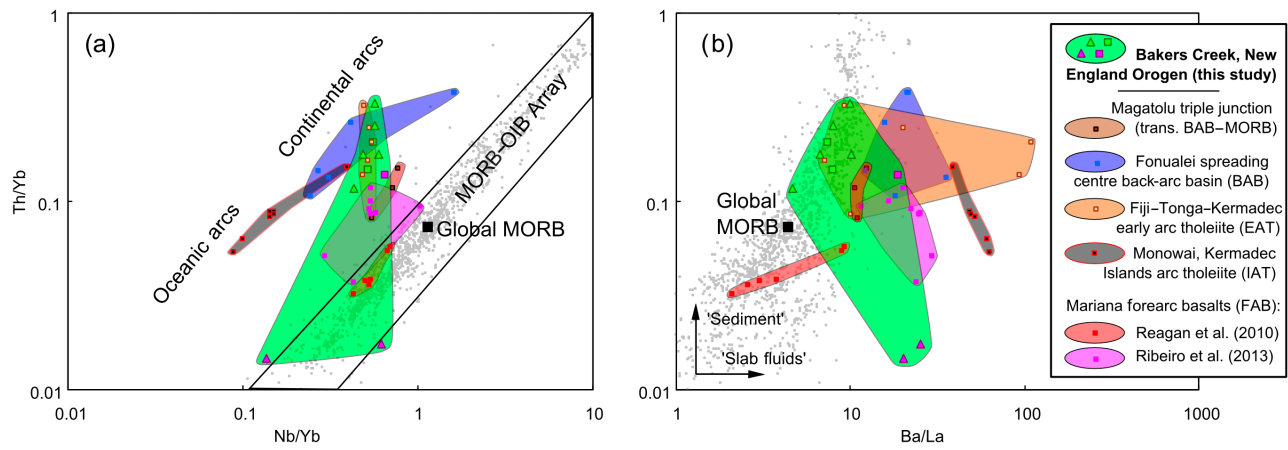

Figure 8. Indicators for subduction zone components, using Th / Yb as a proxy for sedimentary melt, versus (a) Nb / Yb identifying depletion of $\mathrm{Nb}$, after classical subduction zone signatures (Pearce, 2014). (b) Ba / La as a proxy for a fluid-mobile component (Woodhead et al., 2001). Bakers Creek Suite compositions and selected primitive melts from western Pacific arc systems as for Fig. 7.

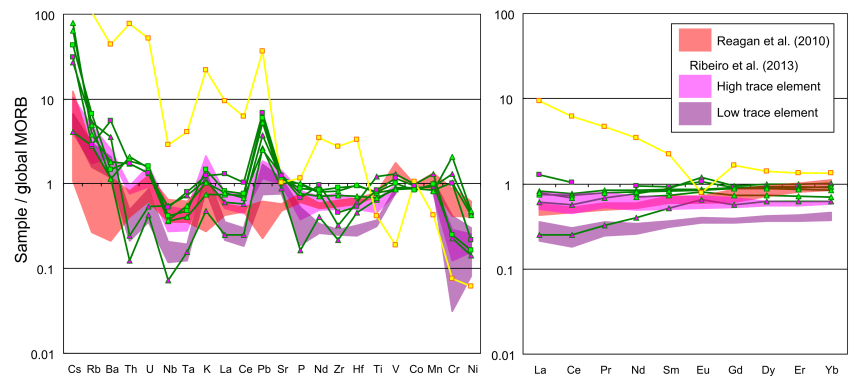

Figure 9. Bakers Creek basaltic melt compositions compared to forearc basalts from Reagan et al. (2010) and Ribeiro et al. (2013) for samples with $\sim 6.6-8.6 \mathrm{wt} \% \mathrm{MgO}$.

and the HFSEs Zr and Hf, all indicate involvement of a FAB component in otherwise arc- or back-arc-like basaltic compositions.

The trace element geochemistry of Bakers Creek Suite samples, and of forearc basalts in general, therefore indicates separation of some components, especially Ti and Zr (Fig. 7), in addition to those attributed to sedimentary or slab-fluid components ( $\mathrm{Th} / \mathrm{Yb}$ and $\mathrm{Ba} / \mathrm{La}$; Fig. 8) that are ordinarily associated, or correlated, with subduction zone associations. The unusual compositions found in the chilled margin of the Days Creek Gabbro may represent early forearcstyle magmas, especially the more extreme characteristics of high $\mathrm{Y} / \mathrm{Zr}$ and low $\mathrm{Th} / \mathrm{Yb}$. As chilled margins, these have been specifically sampled in the field and might be less often captured by random undersea sampling (e.g. Arculus et al., 2015). This particular type of magma seems to have been overwhelmed by later arc-back-arc style magmas (main group Bakers Creek) and the larger Days Creek Gabbro might be an example of a feeder pipe, capturing an early forearc component on its margin and a late back-arc component in its core.

\subsection{Chronology of early NEO magmatism}

The oldest dated Southern NEO intrusives clearly comprise the gabbroic plutons of the Bakers Creek Supersuite (Barney House and Days Creek gabbros); they are clearly resolved by $\mathrm{U}-\mathrm{Pb}$ dating from other intrusive bodies. Other early samples that are not so clearly resolved include the largest compositionally intermediate pluton of the Bakers Creek Supersuite (Bakers Creek Complex), as well as isolated members of the S-type Hillgrove Supersuite (Tia and Rockvale granodiorites, with the age of the latter not well known but still older than $294 \mathrm{Ma}$; possibly also the Blue Knobby Monzogranite and Henry River Granite). The Tia Granodiorite constrains the age of the HTLP Tia Complex (Phillips et al., 2008) to greater than $299.7 \pm 2.0 \mathrm{Ma}$ (recalculated here from data of Cawood et al., 2011); metamorphic zircon in the HTLP Wongwibinda Complex records a similar, or slightly younger, U-Pb age of $296.8 \pm 1.5 \mathrm{Ma}$ (Craven et al., 2012).

As the magmatic pulse accelerated, diverse compositions continued with intrusion of the Jibbinbar Granite at $\sim 298 \mathrm{Ma}$ (Cross et al., 2009), followed by the Rockisle Granite, Dorrigo Mountain Complex, and Mount You You Granite at $\sim 295 \mathrm{Ma}$ (Rosenbaum et al., 2012). This diverse magmatism is also reflected at the same time in volcanic rocks, with the I-type Halls Peak Volcanics and various basaltic flows near the base of the newly opened Barnard Basin (Cawood et al., 2011) and the Alum Rock Volcanics (Roberts et al., 1996).

The major phase of pre-Hunter-Bowen magmatism in the Southern NEO occurred with the climactic emplacement of S-type granites and granodiorites of the Bundarra Supersuite at $\sim 292-285 \mathrm{Ma}$ and many larger plutons of the Hillgrove Supersuite at $\sim 293-288$ Ma (e.g. Hillgrove Monzogranite). Some diversity in magmatic compositions continued throughout this period, with emplacement of the ungrouped Kaloe Granodiorite (Cawood et al., 2011), Bullaganang Granite (Donchak et al., 2007), and Gandar Granodiorite (Rosenbaum et al., 2012), as well as our own AS3- 


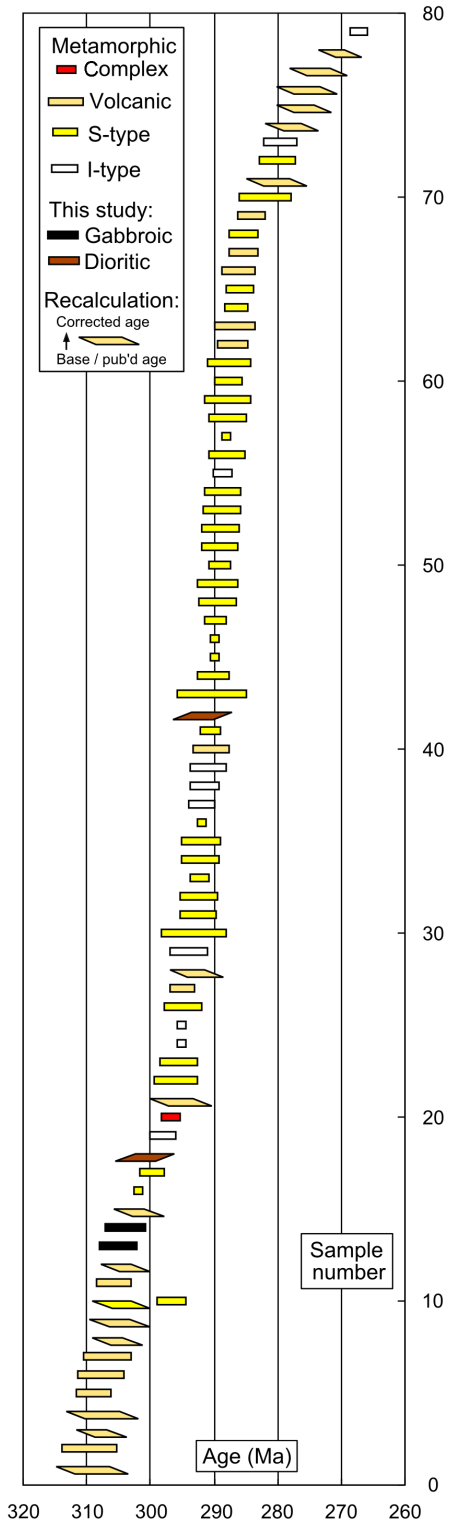

Figure 10. Summary of age determinations for latest Carboniferous to early Permian magmatic rocks of the Southern NEO, corresponding to the first, predominantly S-type granitic magmatism in the orogen. Sources of data in Supplement S4.

corrected age for the Charon Creek Diorite (Bakers Creek Suite).

S-type magmatism persisted until $\sim 280 \mathrm{Ma}$ for the Cheyenne Complex of the Hillgrove Supersuite, and possibly until $\sim 282 \mathrm{Ma}$ for part of the Banalasta Monzogranite of the Bundarra Supersuite (Phillips et al., 2011). This last emplacement of S-type magma was contemporaneous with another burst of I-type magmatism in the form of the Alum Mountain Volcanics ( $\sim 274 \mathrm{Ma}$; Roberts et al., 1995; Li et al., 2014); the more conspicuous low-K, HREE-depleted Greymare Granodiorite (Donchak et al., 2007), similar to the
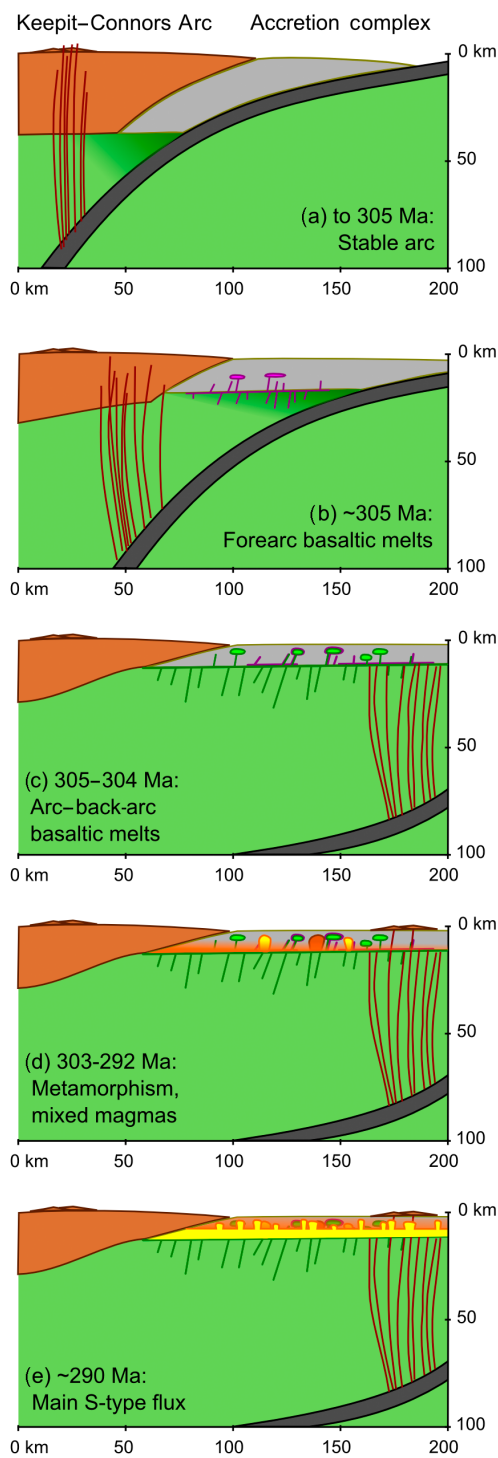

Figure 11. Chronology of early NEO magmatism: (a) Lachlan Orogen subduction zone (Keepit-Connors Arc) at $\sim 310-305 \mathrm{Ma}$; (b) early extension and production of FAB-type melts, emplaced as rare, anomalous chilled margins of the Bakers Creek Suite at $\sim$ $305 \mathrm{Ma}$; (c) continued extension at 305-304 Ma, inducing mantle melting and production of main Bakers Creek Suite gabbros with back-arc (BAB) to arc-like (EAT, IAT) affinities; (d) peak metamorphism in metamorphic complexes (Tia and Wongwibinda) and diverse magmatism, including mafic and felsic components (Bakers Creek and Hillgrove suites) at 303-292 Ma; and (e) main flux of Hillgrove and Bundarra S-type granites at $\sim 290 \mathrm{Ma}$ (see Li et al., 2014, 2015).

Clarence River Supersuite; and finally the $\sim 267$ Ma Barrington Tops Granodiorite (Cawood et al., 2011). This chronology is illustrated in Fig. 10 (see also Supplement S4); thereafter, magmatism following the Hunter-Bowen Orogeny is reviewed by Li et al. (2012). 


\subsection{Tectonic implications}

Magmatism related to a long lived, probably west-dipping subduction zone ceased at $\sim 305 \mathrm{Ma}$ and provided the base of the NEO (Claoué-Long and Korsch, 2003; Roberts et al., 2004, 2006; Jeon et al., 2012; Figs. 10 and 11a); at about the same time, quenching of a new, anomalous or forearc-type mantle-derived magma (Days Creek Gabbro chilled margin) occurred in the Tablelands Complex. This was shortly followed by the main group of Bakers Creek Suite gabbroic melts (Days Creek, Barney House, and Big Bull) at 305$304 \mathrm{Ma}$. The earliest, anomalous magmas in the chilled margin have some unusual characteristics, such as a fluid-mobile high Ba component; low $\mathrm{Zr}$, Th, and potentially lower Ti and higher V; and a general depletion in trace elements. These can be considered as a kind of forearc or $\sim$ FAB-type component (e.g. DC65), indicating decompression melting of the old, depleted mantle wedge and therefore extension of the overlying forearc basin and accretionary prism (Fig. 11b). Evolution to BAB magmatism reflects a combination of a more enriched mantle source and conventional EAT or island arc tholeiite component. It also suggests continued extension (Fig. 11c) related to slab rollback, or perhaps less likely by slab break-off, and could ultimately be driven by reorganisation of the palaeo-Pacific plate. Continued heating and melting of the Tablelands accretion complex during rifting generated high-T metamorphic complexes and the earliest S-type granitic melts of the Hillgrove Suite at $\sim 302$ $300 \mathrm{Ma}$. These, mixed with Bakers Creek Suite gabbroic melts, produced a full spectrum of mafic to felsic compositions (Fig. 11d). Peak melting of fertile greywackes, probably due to underplating of mafic melts, led to the main flux of S-type granites at $\sim 290 \mathrm{Ma}$ (Fig. 11e). While modelling of such processes usually indicates relatively short timescales of $\sim 1 \mathrm{Myr}$ or less for abundant felsic melt production (Annen and Sparks, 2002; Solano et al., 2012), the chronology constructed for the NEO implies that melt mobilisation takes significantly longer, perhaps due to rapid stratification of mafic and felsic melts (preventing later mafic melts from ascending), and importantly involving high melt fractions.

The events above raise the question as to whether the early Permian arc is preserved anywhere in continental Australia or elsewhere. Li et al. (2015) investigated detrital zircons in the Gympie terrane immediately overlying the basal Highbury Volcanics (clinopyroxene-rich basalts; Sivell and Waterhouse, 1988), finding an age cluster at $302 \mathrm{Ma}$. If these zircons are indeed derived from the Highbury Volcanics, which represents the newly established arc, then one can outline (within uncertainty limits of the U-Pb data) the following chronology: (1) the mafic Bakers Creek Suite plutons track the migration of magmatism, with early forearc-like magma (chilled margin of Days Creek Gabbro) crystallising at or just before $\sim 305 \mathrm{Ma}$; (2) these transition to back-arc-like magmas in this area (main Days Creek, Big Bull, and Barney House) at 304-305 Ma, while the arc magmas themselves may be less likely to be observed as they migrate; and (3) arclike magmatism is finally established at $\sim 302 \mathrm{Ma}$ (Highbury Volcanics), albeit so far only indirectly dated by overlying detrital zircons ( $\mathrm{Li}$ et al., 2015). Obviously, a direct U-Pb age for the Highbury Volcanics would provide the best information on its relationship with the Bakers Creek and Hillgrove suites.

\section{Conclusions}

- The Bakers Creek Suite gabbros, associated with the Hillgrove Suite S-type granitoids, record an evolution from an early forearc-like component through normal arc-back-arc style gabbroic magmatism to hybrid melts, with a wide spectrum of intermediate compositions (continuous with the S-type Hillgrove Suite).

- Capture of a FAB-type component occurred in the early basaltic melts of the Bakers Creek Suite. This earliest intrusive magmatism in the NEO occurred at $\sim 305 \mathrm{Ma}$ and was subsequently replaced by incipient arc and back-arc-type magma at 305-304 Ma.

- Rifting, extension of the overlying sedimentary complex, melting of the mantle wedge, and transport of the resulting melts were responsible for the hightemperature, low-pressure metamorphic complexes in the mid-crust and abundant S-type granitic magmas at depth ( $~ 300 \mathrm{Ma}$ and onwards), with peak migration and emplacement of the latter at $\sim 290 \mathrm{Ma}$.

- Ultimately, establishment of the New England Batholith and the Southern NEO, from forearc basin rocks outboard of the Lachlan Orogen, occurred by rifting and rapid evolution through a forearc to a back-arc environment, probably due to slab rollback.

Data availability. The data associated with this publication are available in the Supplement.

\section{The Supplement related to this article is available online at doi:10.5194/se-8-421-2017-supplement.}

Competing interests. The authors declare that they have no conflict of interest.

Acknowledgements. We thank Jenny Zobec for XRF analyses (UoN); Stephen Eggins for LA-ICP-MS analysis (ANU); Daniela Rubatto, Trevor Ireland, Peter Holden, and Peter Lanc for assistance with SHRIMP preparation and measurements; and Ian Williams, Richard Arculus, Joerg Hermann, Colleen Bryant, Pengfei Li, Gordon Lister, Bill Collins, and Robin Offler for 
lengthy discussion about zircon standards, magmatic geochemistry, the NEO, and tectonics. This research was partially supported by an Australian National University PhD Research Scholarship to Seann J. McKibbin, who is currently a postdoctoral fellow of the Research Foundation - Flanders (Fonds Wetenschapplijke Onderszoek; FWO). We thank Pengfei Li, Heejin Jeon, Kim Jessop, and the two anonymous reviewers for constructive comments on the paper, as well as Andrea Di Muro for editorial handling.

Edited by: A. Di Muro

Reviewed by: two anonymous referees

\section{References}

Annen, C. and Sparks, R. S. J.: Effects of repetitive emplacement of basaltic intrusions on thermal evolution and melt generation in the crust, Earth Planet. Sc. Lett., 203, 937-955, 2002.

Arculus, R. J.: Use and abuse of the terms calcalkaline and calcalkalic, J. Petrol., 44, 929-935, 2003.

Arculus, R. J., Ishizuka, O., Bogus, K. A., Gurnis, M., HickeyVargas, R., Aljahdali, M. H., Bandini-Maeder, A. N., Barth, A. P., Brandl, P. A., Drab, L., do Monte Geurra, R., Hamada, M., Jiang, F., Kanayama, K., Kender, S., Kusano, Y., Li, H., Loudin, L. C., Maffione, M., Marsaglia, K. M., McCarthy, A., Meffre, S., Morris, A., Neuhaus, M., Savov, I. P., Sena, C., Tepley III, F. J., van der Land, C., Yogodzinski, G. M., and Zhang, Z.: A record of spontaneous subduction initiation in the Izu-Bonin-Mariana arc, Nat. Geosci., 8, 728-733, 2015.

Arevalo, R. and McDonough, W. F.: Chemical variations and regional diversity observed in MORB, Chem. Geol., 271, 70-85, 2010.

Black, L. P., Kamo, S. L., Williams, I. S., Mundil, R., Davis, D. W., Korsch, R. J., and Foudoulis, C.: The application of SHRIMP to Phanerozoic geochronology, a critical appraisal of four zircon standards, Chem. Geol., 200, 171-188, 2003.

Brown, M.: Hot orogens, tectonic switching, and creation of continental crust: Comment and Reply, Geology, 31, doi:10.1130/0091-7613-31.1.e9, 2003.

Caprarelli, G. and Leitch, E. C.: Magmatic changes during the stabilisation of a cordilleran fold belt: the Late CarboniferousTriassic igneous history of eastern New South Wales, Australia, Lithos, 45, 413-430, 1998.

Cawood, P. A., Leitch, E. C., Merle, R. E., and Nemchin, A. A.: Orogenesis without collision: Stabilizing the Terra Australis accretionary orogen, eastern Australia, Geol. Soc. Am. Bull., 123, 2240-2255, 2011.

Chappell, B. W. and White, A. J. R.: Two contrasting granite types: 25 years later, Aust. J. Earth Sci., 48, 489-499, 2001.

Claoué-Long, J. C. and Korsch, R. J.: Numerical time measurement in the DM Tangorin DDH1 drillcore, in: Geology of the Cranky Corner Basin, edited by: Facer, R. A. and Foster, C. B., New South Wales Department of Mineral Resources, Coal and Petroleum Bulletin, 4, 179-205, 2003.

Class, C. and Lehnert., K.: PetDB expert MORB (midocean ridge basalt) compilation, EarthChem Library, doi:10.1549/IEDA/100060, 2012.

Collins, W. J.: Hot orogens, tectonic switching, and creation of continental crust, Geology, 30, 535-538, 2002.
Collins, W. J. and Richards, S. W.: Geodynamic significance of Stype granites in circum-Pacific orogens, Geology, 36, 559-562, 2008.

Collins, W. J., Offler, R., Farrell, T. R., and Landenberger, B.: A revised Late Palaeozoic-Early Mesozoic tectonic history for the southern New England Fold Belt, NEO '93 Conference Proceedings, 69-84, 1993.

Craven, S. J., Daczko, N. R., and Halpin, J. A.: Thermal gradient and timing of high-T-low-P metamorphism in the Wongwibinda Metamorphic Complex, southern New England Orogen, Australia, J. Metamorph. Geol., 30, 3-20, 2012.

Cross, A. J., Purdy, D. J., Bultitude, R. J., Dhnaram, C. R., and von Gnielinski, F. E.: Joint GSQ-GA NGA geochronology project, New England Orogen and Drummond Basin, 2008, Queensland Geological Record 2009/03, 2009.

Dilek, Y. and Furnes, H.: Ophiolites and their origins, Elements, 10, 93-100, 2014.

Dirks, P. H. G. M., Lennox, P. G., and Shaw, S. E.: Tectonic implications of two Rb/Sr biotite dates for the Tia Granodiorite, southern New England Fold Belt, NSW, Australia, Aust. J. Earth Sci., 39, 111-114, 1992.

Dirks, P. H. G. M., Offler, R., and Collins, W. J.: Timing of emplacement and deformation of the Tia Granodiorite, southern New England Fold Belt, NSW: Implications for the metamorphic history, Aust. J. Earth Sci., 40, 103-108, 1993.

Donchak, P. J. T., Bultitude, R. J., Purdy, D. J., and Denaro, T. J.: Geology and mineralisation of the Texas Region, south-eastern Queensland, Queensland Geology, 11, 25-32, 2007.

Eggins, S. M.: Laser ablation-ICPMS analysis of geological materials prepared as Lithium-borate glasses, Geostandards Newsletter 27, 147-162, 2003.

Escrig, S., Bezos, A., Langmuir, C. H., Michael, P. J., and Arculus R.: Characterizing the effect of mantle source, subduction input and melting in the Fonualei Spreading Center, Lau Basin: Constraints on the origin of the boninitic signature of the back-arc lavas, Geochem. Geophys. Geosys., 13, Q10008, doi:10.1029/2012GC004130, 2012.

Farrell, T. R.: Structural geology and tectonic development of the Wongwibinda Metamorphic Complex, in: New England Orogen, Tectonics and Metallogenesis, edited by: Kleeman, J. D., Department of Geology and Geophysics, University of New England, Armidale, 117-124, 1988.

Flood, R. H. and Shaw, S. E.: Two "S-type" granite suites with low initial 87Sr / 86Sr ratios from the New England Batholith, Australia, Contrib. Mineral. Petr., 61, 163-173, 1977.

Glen, R. A. and Roberts, J.: Formation of oroclines in the New England Orogen, Eastern Australia, in: Stephen Johnston and Gideon Rosenbaum, edited by: Johnston, S. and Rosenbaum, G., J. Virtual Explor., 43, doi:10.3809/jvirtex.2012.00305, 2012.

Gill, J. B.: Geophysical setting of volcanism at convergent plate boundaries, in: Orogenic andesites and plate tectonics, Springer, Berlin, Heidelberg, 44-63, 1981.

Hand, M.: Structural analysis of a deformed subduction-accretion complex sequence, Nowendoc, NSW, in: New England Orogen, Tectonics and Metallogenesis, edited by: Kleeman, J. D., Department of Geology and Geophysics, University of New England, Armidale, 105-116, 1988.

Hensel, H.-D., McCulloch, M. T., and Chappell, B. W.: The New England Batholith: constraints on its derivation from $\mathrm{Nd}$ and $\mathrm{Sr}$ 
isotopic studies of granitoids and country rocks, Geochim. Cosmochim. Ac., 49, 369-384, 1985.

Jenkins, R. B., Landenberger, B., and Collins, W. J.: Late Palaeozoic retreating and advancing subduction boundary in the New England Fold Belt, New South Wales, Aust. J. Earth Sci., 49, 467-489, 2002.

Jenner, F. E. and O'Neill, H. S. C.: Analysis of 60 elements in 616 ocean floor basaltic glasses, Geochem. Geophys. Geosys., 13, Q02005, doi:10.1029/2011GC004009, 2012.

Jeon, H., Williams, I. S., and Chappell, B. W.: Magma to mud to magma: Rapid crustal recycling by Permian granite magmatism near the eastern Gondwana margin, Earth Planet. Sc. Lett., 319320, 104-117, 2012.

Keller, N. S., Arculus, R. J., Hermann, J., and Richards, S.: Submarine back-arc lava with arc signature: Fonualei Spreading Center, northeast Lau Basin, Tonga, J. Geophys. Res., 113, B08S07, doi:10.1029/2007JB005451, 2008.

Kemner, F., Haase, K. M., Beier, C., Krumm, S., and Brandl, P. A.: Formation of andesite melts and $\mathrm{Ca}$-rich plagioclase in the submarine Monowai volcanic system, Kermadec arc, Geochem. Geophys. Geosys., 16, 4130-4152, doi:10.1002/2015GC005884, 2015.

Kemp, A. I. S., Hawkesworth, C. J., Collins, W. J., Gray, C. M., Blevin, P. L., and EIMF: Isotopic evidence for rapid continental growth in an extensional accretionary orogen: The Tasmanides, eastern Australia, Earth Planet. Sc. Lett., 284, 455-466, 2009.

Kent, A. R. J.: Geochronology and geochemistry of Palaeozoic intrusive rocks in the Rockvale region, southern New England Orogen, New South Wales, Aust. J. Earth Sci., 41, 365-379, 1994.

Korsch, R. J.: A framework for the Palaeozoic geology of the southern part of the New England Geosyncline, J. Geol. Soc. Aust., 25, 339-355, 1977.

Landenberger, B., Farrell, T. R., Offler, R., Collins, W. J., and Whitford, D. J.: Tectonic implications of Rb-Sr biotite ages for the Hillgrove Plutonic Suite, New England Fold Belt, N.S.W., Australia, Precambrian Res., 71, 251-263, 1995.

Langmuir, C. H., Bézos, A., Escrig, S., and Parman, S. W.: Chemical systematics and hydrous melting of the mantle in back-arc basins. In: Back-arc spreading systems: Geological, biological, chemical, and physical interactions, Geophys. Monogr. Ser., 166, 87-146, 2006.

Le Bas, M. J. and Streckeisen, A. L.: The IUGS systematics of igneous rocks, J. Geol. Soc. London, 148, 825-833, 1991.

Leitch, E. C.: The Geological Development of the Southern Part of the New England Fold Belt, J. Geol. Soc. Aust., 21, 133-156, doi:10.1080/00167617408728840, 1974.

Leitch, E. C.: Plate tectonic interpretation of the Paleozoic history of the New England Fold Belt, Bull. Geol. Soc. Am., 86, 141$144,1975$.

Li, P.-F., Rosenbaum, G., and Rubatto, D.: Triassic asymmetric subduction rollback in the southern New England Orogen (eastern Australia): the end of the Hunter-Bowen Orogeny, Aust. J. Earth Sci., 59, 965-981, 2012.

Li, P.-F., Rosenbaum, G., and Vasconcelos, P.: Chronological constraints on the Permian geodynamic evolution of eastern Australia, Tectonophysics, 617, 20-30, 2014.

Li, P.-F., Rosenbaum. G., Yang, J.-H., and Hoy, D.: Australianderived detrital zircons in the Permian-Triassic Gympie terrane (eastern Australia): Evidence for an autochthonous origin, Tectonics, 34, 858-874, doi:10.1002/2015TC003829, 2015.

McCulloch, M. T. and Gamble, J. A.: Geochemical and geodynamical constraints on subduction zone magmatism, Earth Planet. Sc. Lett., 102, 358-374, 1991.

Meffre, S., Falloon, T. J., Crawford, T. J., Hoernle, K., Hauff, F., Duncan, R. A., Bloomer, S. H., and Wright, D. J.: Basalts erupted along the Tongan fore arc during subduction initiation: Evidence from geochronology of dredged rocks from the Tonga fore arc and trench, Geochem. Geophys. Geosys., 13, 1-17, 2012.

Pearce, J.: Immobile element fingerprinting of ophiolites, Elements, 10, 101-108, 2014.

Pearce, J. A. and Stern, R. J.: Origin of back-arc basin magmas: Trace element and isotope perspectives, In: Back-arc spreading systems: Geological, biological, chemical, and physical interactions, Geophys. Monogr. Ser., 166, 63-86, 2006.

Phillips, G., Hand, M., and Offler, R.: P-T-t deformation framework of an accretionary prism, southern New England Orogen, eastern Australia: Implications for blueschist exhumation and metamorphic switching, Tectonics, 27, TC6017, doi:10.1029/2008TC002323, 2008.

Phillips, G., Landenberger, B., and Belousova, E. A.: Building the New England Batholith, eastern Australia - Linking granite petrogenesis with geodynamic setting using Hf isotopes in zircon, Lithos, 122, 1-12, 2011.

Reagan, M. K., Ishizuka, O., Stern, R. J., Kelley, K. A., Ohara, Y., Blichert-Toft, J., Bloomer, S. H., Cash, J., Fryer, P., Hanan, B. B., Hickey-Vargas, R., Ishii, T., Kimura, J.-I., Peate, D. W., Rowe, M. C., and Woods, M.: Fore-arc basalts and subduction initiation in the Izu-Bonin-Mariana system, Geochem. Geophys. Geosys., 11, 1-17, 2010.

Ribeiro, J. M., Stern, R. J., Kelley, K. A., Martinez, F., Ishizuka, O., Manton, W. I., and Ohara, Y.: Nature and distribution of slabderived fluids and mantle sources beneath the Southeast Mariana forearc rift, Geochem. Geophys. Geosys., 14, 4584-4607, 2013.

Roberts, J., Claoué-Long, J. C., Jones, P. J., and Foster, C. B.: SHRIMP zircon age control of Gondwanan sequences in Late Carboniferous and Early Permian Australia, in: Dating and correlating biostratigraphically barren strata, edited by: Dunnay, R. E. and Hailwood, E. A., Geological Society of London Special Publication, 89, 145-174, 1995.

Roberts, J., Claoué-Long, J. C., and Foster, C. B.: SHRIMP zircon dating of the Permian System of eastern Australia, Aust. J. Earth Sci., 43, 401-421, 1996.

Roberts, J., Offler, R., and Fanning, M.: Upper Carboniferous to Lower Permian volcanic successions of the Carroll-Nandewar region, northern Tamworth Belt, southern New England Orogen, Australia, Aust. J. Earth Sci., 51, 205-232, 2004.

Roberts, J., Offler, R., and Fanning, M.: Carboniferous to Lower Permian stratigraphy of the southern Tamworth Belt, southern New England Orogen, Australia: boundary sequences of the Werrie and Rouchel blocks, Aust. J. Earth Sci., 53, 249-284, 2006.

Rosenbaum, G., Li, P.-F., and Rubatto, D.: The contorted New England Orogen (eastern Australia): New evidence from U$\mathrm{Pb}$ geochronology of early Permian granitoids, Tectonics, 31, TC1006, doi:10.1029/2011TC002960, 2012.

Shaanan, U., Rosenbaum, G., and Wormald, R.: Provenance of the early Permian Nambucca block (eastern Australia) and implica- 
tions for the role of trench retreat in accretionary orogens, Geol. Soc. Am. Bull., 127, 1052-1063, 2015.

Shaw, S. E. and Flood, R. H.: The New England Batholith, eastern Australia: Geochemical vartiations in time and space, J. Geophys. Res., 86, 10530-10544, 1981.

Shervais, J. W.: Ti-V plots and the petrogenesis of modern and ophiolitic lavas, Earth Planet. Sc. Lett., 59, 101-118, 1982.

Sivell, W. J. and Waterhouse, J. B.: Petrogenesis of Gympie Group volcanics: evidence for remnants of an early Permian volcanic arc in eastern Australia, Lithos, 21, 81-95, 1988.

Solano, J. M. S., Jackson, M. D., Sparks, R. S. J., Blundy, J. D., and Annen, C.: Melt segregation in deep crustal hot zones: A mechanism for chemical differentiation, crustal assimilation and the formation of evolved magmas, J. Petrol., 53, 1999-2026, 2012.

Spandler, C. and Pirard, C.: Element recycling from subducting slabs to arc crust: A review, Lithos, 170-171, 202-223, 2013.

Timm, C., Graham, I. J., de Ronde, C. E. J., Leybourne, M. I., and Woodhead, J.: Geochemical evolution of Monowai volcanic center: New insights into the northern Kermadec arc subduction system, SW Pacific, Geochem. Geophys. Geosys., 12, Q0AF01, doi:10.1029/2011GC003654, 2011.
Todd, E., Gill, J. B., and Pearce, J. A.: A variably enriched mantle wedge and contrasting melt types during arc stages following subduction initiation in Fiji and Tonga, southwest Pacific, Earth Planet. Sc. Lett., 335-336, 180-194, 2012.

Woodhead, J. D., Hergt, J. M., Davidson, J. P., and Eggins, S. M.: Hafnium isotope evidence for "conservative" element mobility during subduction zone processes, Earth Planet. Sc. Lett., 192, 331-346, 2001.

Zimmer, M. M., Plank, T., Hauri, E. H., Yogodzinski, G. M., Stelling, P., Larsen, J., Singer, B., Jicha, B., Mandeville, C., and Nye, C. J.: The role of water in generating the calc-alkaline trend: New volatile data for Aleutian magmas and a new tholeiitic index, J. Petrol., 51, 2411-2444, 2010. 